\title{
Evolutionary and ecological patterns in body size, shape, and ornamentation in the Jurassic bivalve Chlamys (Chlamys) textoria (Schlotheim, 1820)
}

\author{
Sabine Nürnberg ${ }^{1}$, Martin Aberhan ${ }^{*}, 1$ and Richard A. Krause ${ }^{2}$ \\ ${ }^{1}$ Museum für Naturkunde, Leibniz Institute for Research on Evolution and Biodiversity at the Humboldt University Berlin, Invalidenstr. 43, \\ 10115 Berlin, Germany. E-mail: martin.aberhan@mfn-berlin.de \\ 2 Department of Geology and Geophysics, Yale University, 210 Whitney Ave., New Haven, CT, U.S.A.
}

\begin{abstract}
Received 20 July 2007

Accepted 21 September 2011

Published 21 February 2012

\section{Key Words}

Cope's Rule

Bergmann's Rule

Trends

Predation

Morphology

Palaeoecology

Changes in body size have been the subject of numerous palaeontological and neontological studies, but despite several general postulated "rules", the underlying processes controlling them are still incompletely understood, and their broad applicability is debated. Here we utilise morphological and ecological data from the Jurassic marine bivalve Chlamys textoria (Schlotheim, 1820) to analyse spatial and temporal trends in body size and ornamentation. We find: (1) fluctuations in body size during the Jurassic and no support for Cope's rule (the tendency to increase body size over geological time within an individual lineage); (2) a gradual increase in the average height to length ratio of the valves during the Jurassic. In the absence of any obvious adaptive advantage we suggest genetic drift as the causal mechanism; (3) a significantly larger mean body size in mid-palaeolatitudes than in the Jurassic tropics, providing evidence for the validity of Bergmann's rule (the assertion that body mass increases with latitude); and (4) a complex relationship between the number of plicae and the environment, which we explain as an improvement towards camouflaging the shell.
\end{abstract}

\section{Introduction}

Body size is among the most obvious characteristics of an organism, and it is closely related to the biotic and abiotic environment as well as life-history traits. Because of its implications for almost every aspect of life, research on body size has a long history in evolutionary biology, ecology, and palaeontology. Numerous museum collections of fossil marine invertebrates facilitate body-size research over broad temporal intervals, making it possible to recognize distinct patterns in the evolution of body size. Because they are characterised by high preservation potential, global distribution, and high abundance, fossil marine bivalves have been, and continue to be, the subject of numerous studies on body size (e.g. Hallam 1975a; Jablonski 1997; Roy et al. 2000; Aberhan et al. 2006). To date, most analyses on body size have concentrated on patterns based on datasets that include a multitude of taxa from the genus le- vel up to the order level. Our approach, in contrast, focuses on a single bivalve species: the Jurassic marine pectinid Chlamys textoria (Schlotheim, 1820; Fig. 1). This should be seen as an attempt to minimise taxonomic "noise" by considering a single species that is likely to exhibit similar changes in body size in response to ecological stimuli throughout its range. This control on changes in body size may allow us to uncover patterns, which are otherwise obscured in studies that consider many species with varied size-related responses to external stimuli. For example, although it is widely accepted that temperature is one of the most important physical factors controlling body size in ectotherms (Nicol 1964; Atkinson 1994), different organisms respond to changes in temperature in different ways (Heilmayer 2004). Thus, in a study on the influence of temperature on body size, there might be no visible trend because of differing long-term morphologic/evolutionary responses of the various species studied.

\footnotetext{
* Corresponding author
} 


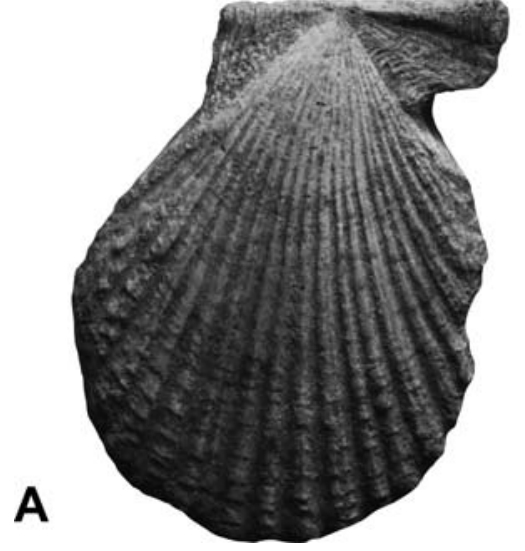

B

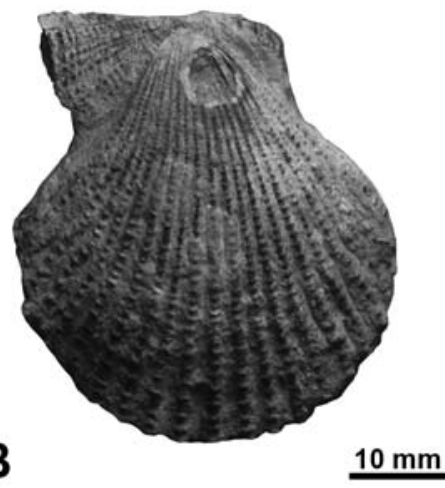

Figure 1. Chlamys (Chlamys) textoria (Schlotheim, 1820). A. Right valve, Oxfordian, Yonne, France; syntype of Pecten subarticulatus d'Orbigny, 1850, housed in the Muséum National d'Histoire Naturelle, Paris (R07365); B. Left valve, Bathonian, HauteMarne, France; holotype of Chlamys bathonica Cossmann, 1911, housed in the Muséum National d'Histoire Naturelle, Paris (J08245).
General predictions have been made on the body size of endotherms and some of these have been proposed to apply for ectotherms as well. The widespread tendency of lineages to evolve towards larger physical size, known as Cope's rule (Cope 1896; Stanley 1973; Hone \& Benton 2005), has been recognized in numerous plant, invertebrate and vertebrate groups (Newell 1949; McFadden 1992; Alroy 1998; Hone \& Benton 2005; Hunt \& Roy 2006; Hone \& Benton 2007; Hone et al. 2008; Novack-Gottshall \& Lanier 2008), but numerous exceptions exist as well (Arnold et al. 1995; Dommergues et al. 2002; Knouft \& Page 2003; Poulin 2005; Moen 2006; Butler \& Goswami 2008; Monroe \& Bokma 2010). Marine bivalves in particular have played an important role in research on the validity of Cope's rule. Phyletic size increase was reported for Jurassic bivalves and ammonites (Hallam 1975a, 1978, 1998). However, using an extensive dataset of Cretaceous bivalve body sizes, Jablonski $(1996,1997)$ rejected Cope's rule as an evolutionary generalisation and showed, for example, that a pattern of "increased variance" was an equally important pathway in body-size evolution.

Another important concept is Bergmann's rule (Dayan et al. 1991; Hunt \& Roy 2006; Chown \& Gaston 2010; Hunt et al. 2010), the latitudinal trend of body size, which states that body size increases with increasing latitude. Although latitude has no environmental significance by itself, it is a proxy for a number of environmental variables including mean annual temperature, oxygen availability, seasonality, and productivity, all considered to influence growth rates and body size (Roy et al. 2000). Bergmann's rule has been tested for both endotherms and ectotherms, but considerable debate still exists about the generality of the pattern and the underlying processes (Atkinson 1994; Renaud et al. 1999; Roy \& Martien 2001; Hunt et al. 2010).

In addition to abiotic factors (e.g., water temperature, nutrient availability, oxygen supply) controlling body size, predation pressure is thought to influence the overall size distribution of a population by reducing the number of small individuals and leaving the largest individuals that have attained a 'size refuge' (Paine 1976). Predation-related size sorting may be an im- portant factor in Jurassic bivalves because predator diversity and abundance increased during the Jurassic (Bambach 2002; Aberhan et al. 2006). The possible pathways for a pectinid bivalve species to adapt to increasing predation pressure include an increase in growth rate (and early maturity), greater adult size, greater valve thickness, strengthening of the shell by constructing fewer plicae with higher amplitudes, and improving predator avoidance strategies such as swimming and camouflage.

The aim of the present study is to take advantage of a single species approach and search for distinct patterns and trends in the distribution of body size and phenotypes in space and time. Emergent patterns will be discussed in light of the above-mentioned general concepts to test how far these can be applied to a marine bivalve species.

\section{Material and methods}

Our analyses focus on the epifaunal pectinid bivalve Chlamys (Chlamys) textoria (Schlotheim, 1820). The oldest reliable records of the species are from the earliest Hettangian and it ranges throughout all Jurassic stages into the late Tithonian. Owing to its longevity, the ability to adapt to a wide range of environmental conditions, and its fairly wide geographic distribution (Fig. 2; Johnson 1984), the chosen species seems well suited for the purpose of the study.

Herein, we follow the extended species definition of Johnson (1984), who assigned the European Jurassic specimens of the bivalve genus Chlamys to only three morphospecies. He distinguished Chlamys textoria from the other two Jurassic species, Chlamys valoniensis (Defrance, 1825) and Chlamys pollux (d'Orbigny, 1850), by the presence of variably spaced imbricate lamellae on the plicae, thus including a long list of former nominal species.

The dataset used in this study consists of measurements of specimens from extensive collections housed in the following institutions: Museum für Naturkunde, Berlin; Muséum National d'Histoire Naturelle, Paris; GeoZentrum Nordbayern, Erlangen; Naturhistorisches Museum Basel; Bayerische Staatssammlung für Paläontologie and Geologie, Munich. Measurements of specimens were combined with equivalent measurements taken from images and from data tables from the following taxonomic publications: Aberhan (1994, 1998a), Agrawal (1956), Ahmad (1999), Allasinaz (1962), Berini (1957), Bertuletti (1962), Calzada \& Radulovic (1987), Cantaluppi \& Corti (1969), Contejean (1859), Cottreau (1925-1932), Cox (1965), Damborenea (2002), Dechaseaux (1936), Delvene (2001), Ernst (1923), Fischer 


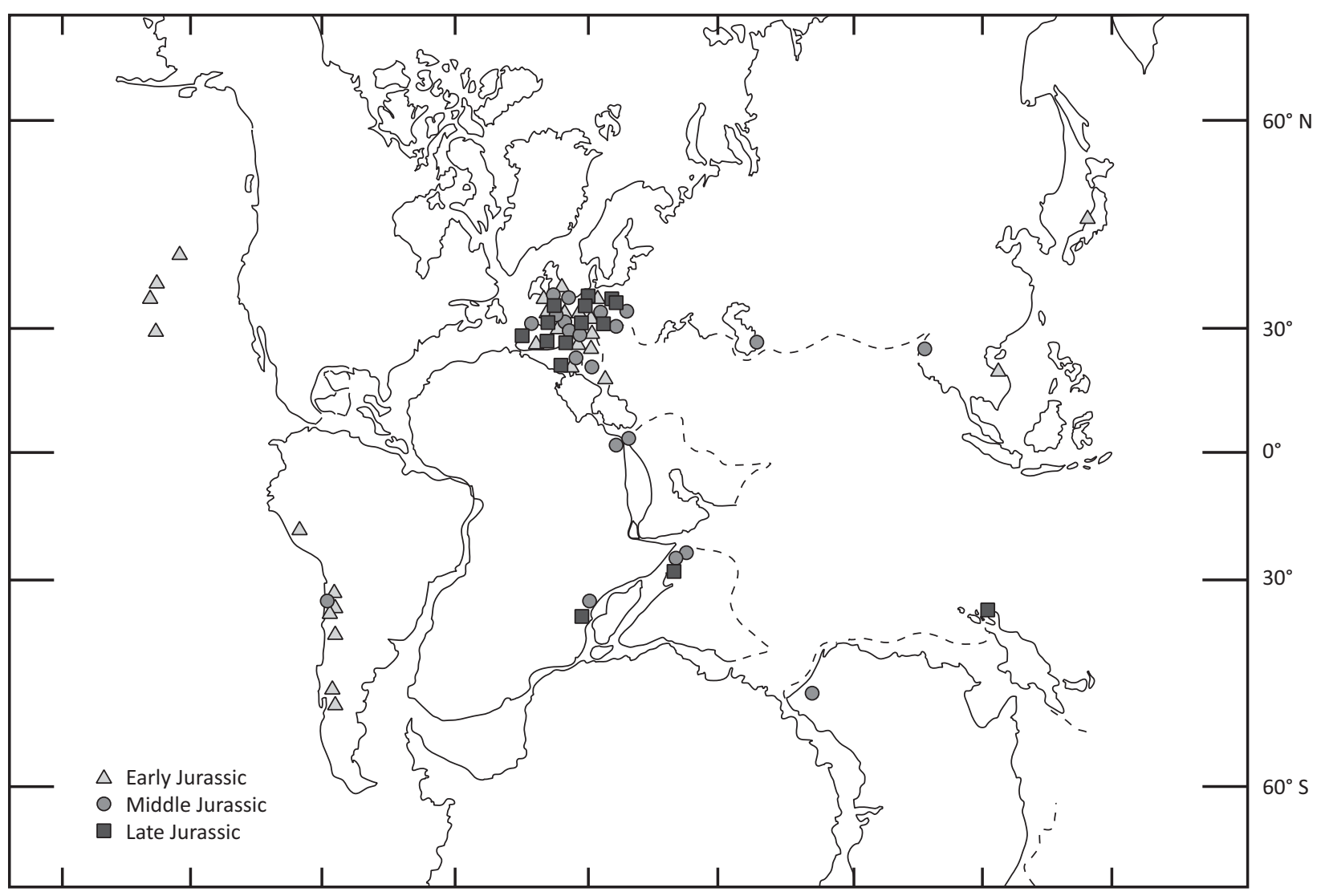

Figure 2. Geographic distribution of the studied specimens of the Jurassic bivalve Chlamys textoria (Schlotheim, 1820). Palaeolatitudes range from $44^{\circ} \mathrm{S}$ (Piedra Pintada, Argentina) to $48^{\circ} \mathrm{N}$ (Kamikawara, Japan). Base map modified from Hallam (1975b). The occurrences in the north-eastern Pacific are from the Stikinia terrane (e.g. Aberhan 1998b).

(1964), Fürsich \& Werner (1988), Gaetani (1970), Gemmellaro \& di Blasi (1874), Greco (1898), Greppin (1893, 1898-1900), Hayami (1957), Hurst (1992), Jaitly et al. (1995), Johnson (1984), Kochanová (1979), Kuhn (1936, 1938), Lentini (1973), Loriol (1904), Melville (1956), Paris \& Richardson (1915), Scholz (2005), Sibiriakova (1961), Skwarko (1974), Staesche (1926), Thurmann \& Etallon (1862), Tilmann (1917), Tzankov \& Boncev (1932), Vu Khuc et al. (1991), Wandel (1936), Weaver (1931), Wisniewska-Zelichowska (1971), Yamani (1975), Yin (1931), and Yin \& Fürsich (1991).

Measurements of photographs of specimens can introduce a bias because distortions can occur at any stage in the photographic process. However previous research suggests that this bias is negligible for small specimens (Kowalewski et al. 2000) and invariant across a wide range of shapes and sizes (Sime \& Ferguson 2003). Furthermore, specimens figured in photographic illustrations represent a biased sample with respect to the actual size distribution of the population from which they were chosen, but this bias is also invariant across a wide range of species and environments (Krause et al. 2007). We have investigated these potential biases by restricting the analyses to specimens which were measured by ourselves. These analyses yielded qualitatively similar results to those obtained using the entire dataset.

The dataset used herein consists of 592 individuals of Ch. textoria from 296 localities. As an approximation of body size, the geometric mean of height $(\mathrm{H})$ and length $(\mathrm{L})$ of each specimen was determined [geometric mean $=\sqrt{(H \times L)}$ ]. The geometric mean is a standard metric used in most recent studies of bivalve size dynamics (Jablonski 1996, 1997; Roy et al. 2000) because it is strongly correlated with more complex size metrics and thus provides a more accurate size assessment than single linear measurements (Kosnik et al. 2006).

In addition, we counted the number of plicae and, following Johnson (1984), assigned each specimen to one of three different pheno- types: "coarse" (17-26 plicae), "intermediate" (27-36 plicae), and "fine" (> 36 plicae).

The dataset was supplemented with information on lithology, grain size, and depositional environment for each locality as far as available. We distinguished between siliciclastics, carbonates, and mixed lithologies; coarse- and fine-grained sediments; and shallow-water (non-reef habitats above storm wave base), deeper water (below storm wave base), and reef and reef-associated habitats.

To determine the latitudinal distribution in body size, the coordinates for each locality were identified from the collector's description and then used to calculate the appropriate palaeopositions. On this basis, the localities were assigned either to the tropics (up to $35^{\circ}$ north and south) or to the non-tropics. A more narrow but traditional definition of the tropics between $23^{\circ} \mathrm{N}$ (Tropic of Cancer) and $23^{\circ} \mathrm{S}$ (Tropic of Capricorn) was deemed inadequate for this study because the warmer worldwide climate of the Jurassic would have resulted in tropical conditions at latitudes higher than today. Occurrences in areas with a high probability of conditions favourable for coastal upwelling and therefore high productivity were determined with the palaeoclimatic modeling maps of Golonka et al. (1994).

To avoid a bias in favour of localities with a high number of specimens, a "standardised" dataset was constructed in addition to the main dataset. In the "standardised" dataset, the median values of the measured parameters were used for localities with more than one specimen. The analyses were performed at stage level, with the duration of the time bins ranging from 3.0 million years (Myr) for the Bathonian to $7.4 \mathrm{Myr}$ for the Toarcian (using durations as defined in Gradstein \& Ogg 2004). All analytical scripts were written in the R Programming Environment (R Development Core Team 2011). For statistical analyses the level of significance $(\alpha)$ was set at 0.05 . 
Table 1. Analyses of body shape and body size of the Jurassic pectinid bivalve Chlamys textoria in the latitudinal cline using the "standardised" dataset. H - shell height; L - shell length.

\begin{tabular}{llll}
\hline Analyses & & Results & \\
\hline Body shape & Net change throughout the Jurassic & Kruskal-Wallis H & $p=0.03$ \\
& Trend in H/L through time & $r_{\mathrm{s}}=0.238$ & $p<0.001$ \\
& - lower range $(10 \%)$ of values & $r_{\mathrm{s}}=0.582$ & $p=0.001$ \\
& - upper range $(10 \%)$ of values & $r_{\mathrm{s}}=0.480$ & $p=0.01$ \\
& Difference in body shape for reefs vs. non-reefs & Mann-Whitney U & $p<0.001$ \\
& Trend in H/L through time in level bottom habitats & $r_{\mathrm{s}}=0.246$ & $p=0.006$ \\
Latitudinal gradient & Increase in body size with absolute palaeolatitude & $r_{\mathrm{s}}=0.238$ & $p<0.001$ \\
& - in shallow-water & $r_{\mathrm{s}}=0.389$ & $p=0.005$ \\
& - in deeper water & $r_{\mathrm{s}}=0.273$ & $p=0.04$ \\
& Difference in body size for tropics vs. non-tropics & Mann-Whitney $U$ & $p=0.01$ \\
\hline
\end{tabular}

\section{Results}

Unless otherwise indicated, the results presented here use the complete dataset. We include results for the "standardised" dataset only where they differ substantially or provide additional insights. To show the degree of support, the corresponding results for the "standardised" dataset are summarized in Table 1.

The measured parameters exhibit a right-skewed body-size distribution (Fig. 3) with a mean body size of $35.0 \mathrm{~mm}(\mathrm{SD}=14.1$, median $=33.6 \mathrm{~mm})$. The largest specimen comes from early Tithonian reefs at Laisacker, southern Germany, with a geometric mean of $109.0 \mathrm{~mm}$ (Yamani 1975). The temporal variation in the relative abundance of specimens in the various environmental and lithological categories is given in Figure 4.

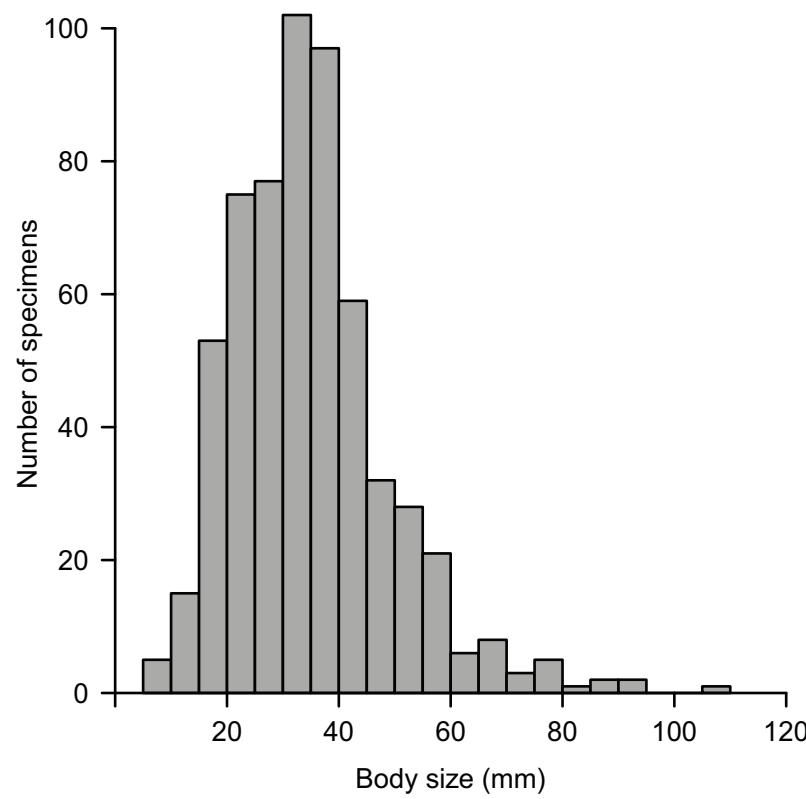

Figure 3. Body size distribution of Chlamys textoria (Schlotheim, 1820), measured as geometric mean of shell height and shell length for all 592 specimens included in the dataset.
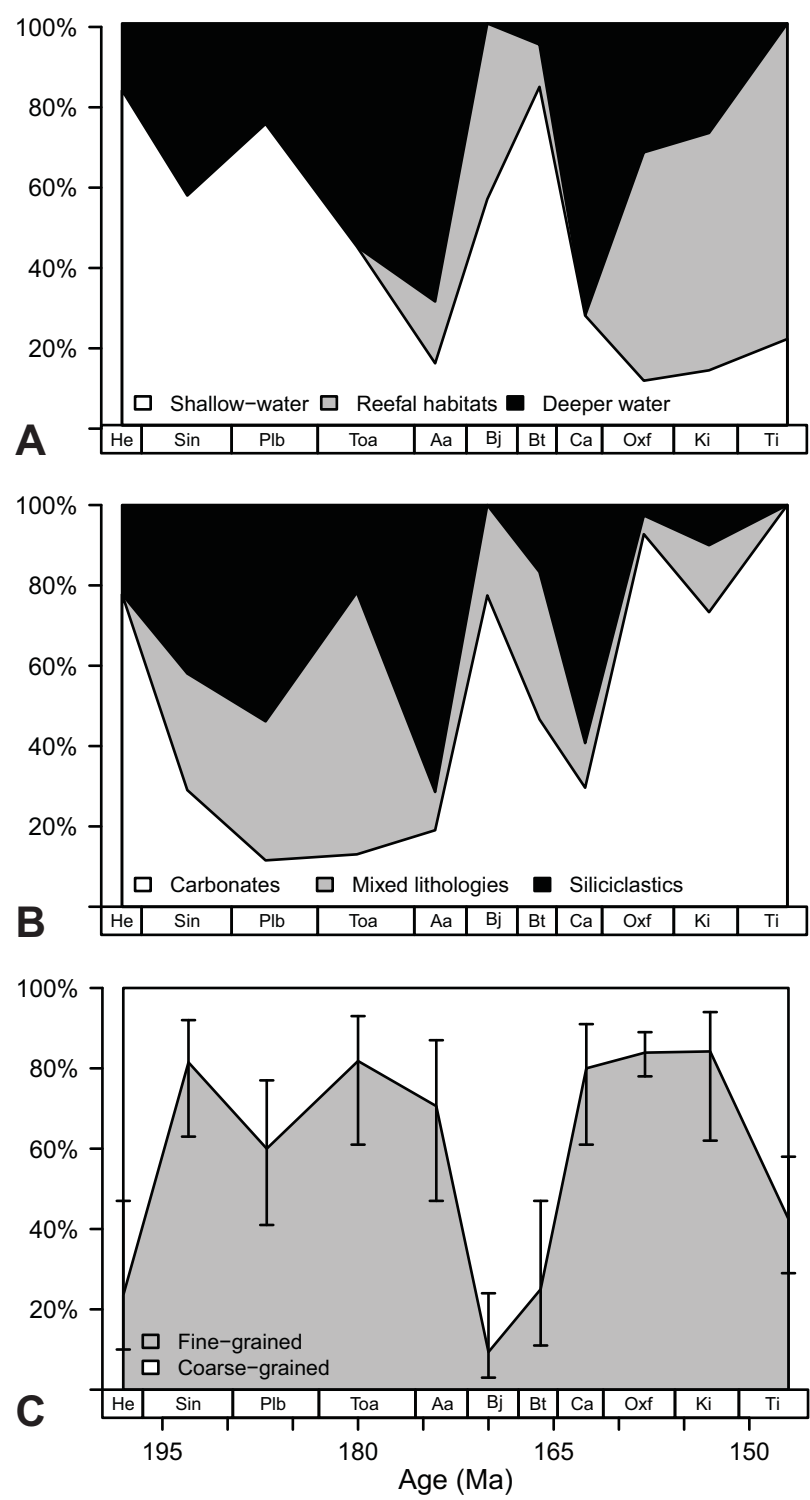

Figure 4. Time series of the relative abundance of specimens in the various environmental (A), lithological (B), and grain size categories (C). Error bars represent $95 \%$ confidence intervals. Abbreviations of time intervals: He - Hettangian; Sin Sinemurian; Plb - Pliensbachian; Toa - Toarcian; Aa - Aalenian; Bj - Bajocian; Bt - Bathonian; Ca - Callovian; Oxf Oxfordian; Ki - Kimmeridgian; $\mathbf{T i}$ - Tithonian. 


\section{Body size through time}

There is no significant trend in the body size of Ch. textoria from the Hettangian to the Tithonian. This holds true for mean and median body size as well as for maximum body size and variance in body size (Fig. 5). Similarly, analysing body size within environmental and lithological categories fails to identify any temporal trends or significant differences in mean body size between the categories. This applies to fine-grained versus coarse-grained substrates, siliciclastic versus carbonate versus mixed lithologies, and shallow-water versus deeper water versus reefal environments (Table 2).

\section{Evolutionary changes in body shape}

Nearly every specimen is slightly higher than it is long (mean $\mathrm{H} / \mathrm{L}=1.12, \mathrm{SD}=0.08$ ). There is also a limited, but highly significant, increase in the height-length ratio $(\mathrm{H} / \mathrm{L})$ with time (Fig. 6), starting from an average $\mathrm{H} / \mathrm{L}$ of 1.06 in the Hettangian and culminating in an average $\mathrm{H} / \mathrm{L}$ of 1.16 in the Tithonian (Kruskal-Wallis $H$, $p<0.001$ ). In total this represents a net change in body shape of $8.8 \%$ over a time period of approximately $50 \mathrm{Myr}$. This trend persists when restricting the analysis to specimens that fall within a certain size class (e.g. specimens with a body size range from 25 to $35 \mathrm{~mm}$ :
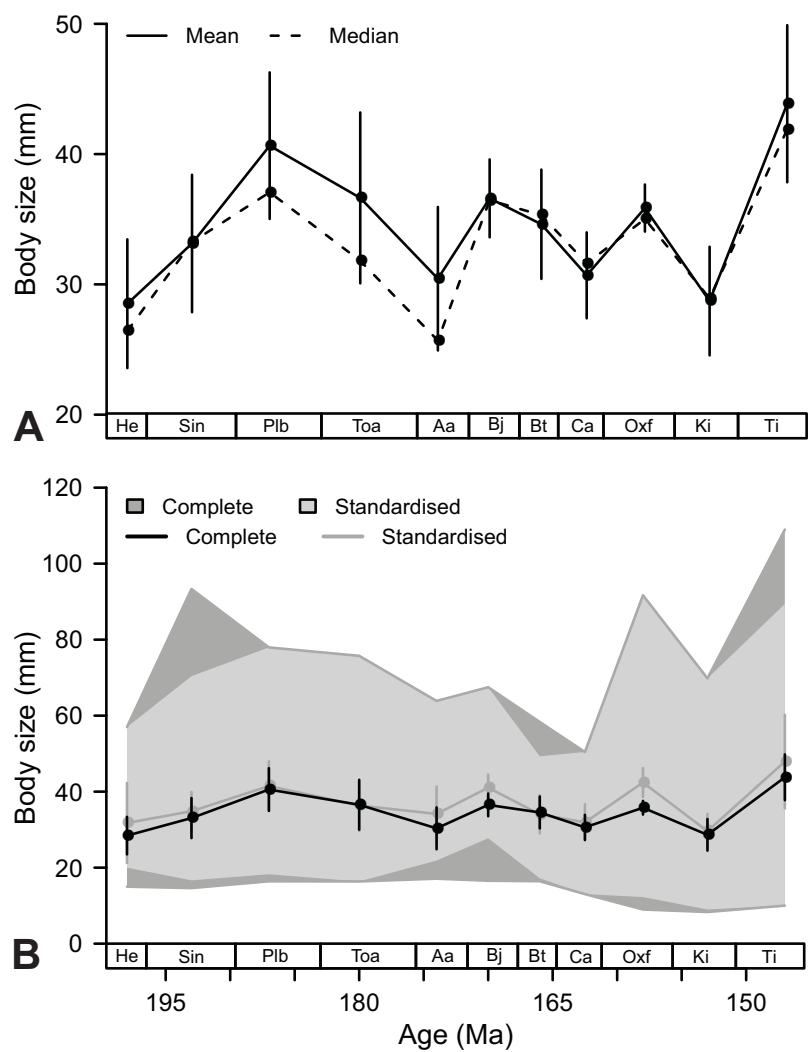

Figure 5. Body size of Chlamys textoria (Schlotheim, 1820) through time. A. Mean and median body size; B. Maximum body size and variance in body size for the complete and the "standardised" data set. Error bars represent 95\% confidence intervals. For abbreviations of Jurassic stages see Figure 4.
Table 2. Body size, expressed as the geometric mean of height and length, of Chlamys textoria in various environmental, lithological, and grain size categories. SD - standard deviation; SE - standard error. *The higher average body size in mixed lithologies is mainly due to specimens from high productivity areas in the Early Jurassic of Chile. ${ }^{* *}$ The higher average body size in coarse-grained sediments is generated by Late Jurassic specimens. If excluded, there is no difference between the two lithological groupings.

\begin{tabular}{lllll}
\hline & & $\begin{array}{c}\text { Mean } \\
(\mathrm{mm})\end{array}$ & SD & $\begin{array}{l}\text { SE of } \\
\text { mean }\end{array}$ \\
\hline Palaeo- & Shallow-water & 36.57 & 15.42 & 1.35 \\
environment & Reef/reef-associated & 33.74 & 14.69 & 1.12 \\
& Deeper water & 35.63 & 11.12 & 0.98 \\
Lithology & Carbonates & 34.80 & 13.87 & 0.73 \\
& Mixed & $38.54^{*}$ & 16.10 & 1.87 \\
& Siliciclastics & 32.62 & 13.32 & 1.42 \\
Grain size & Fine-grained & 33.55 & 12.81 & 0.74 \\
& Coarse-grained & $36.94^{* * *}$ & 15.66 & 1.26 \\
\hline
\end{tabular}

$\left.r_{\mathrm{s}}=0.220, p=0.005\right)$. If we analyse individual geographic regions for which we have sufficient data from each temporal bin, a significant trend of $\mathrm{H} / \mathrm{L}$ remains (e.g., southern Germany and central France: $r_{\mathrm{s}}=0.202$, $p=0.008$, and $r_{\mathrm{s}}=0.370, p=0.004$, respectively). Furthermore, the trend persists when excluding European specimens $\left(r_{\mathrm{s}}=0.231, p=0.004\right)$.

To discriminate between a driven and a passive trend, we used McShea's (1994) minimum test. In a driven positive trend the minimum values should increase along with the maximum values. Hence, it is appropriate to focus on specimens representing the lower and the upper range of the body shape distribution per interval separately. Limiting the analysis to those $10 \%$ of specimens per stage with the lowest or highest $\mathrm{H} / \mathrm{L}$ values reveals significant positive correlations for both the lower and the upper end of the range (Fig. 7). Although the increase in the upper range is higher than

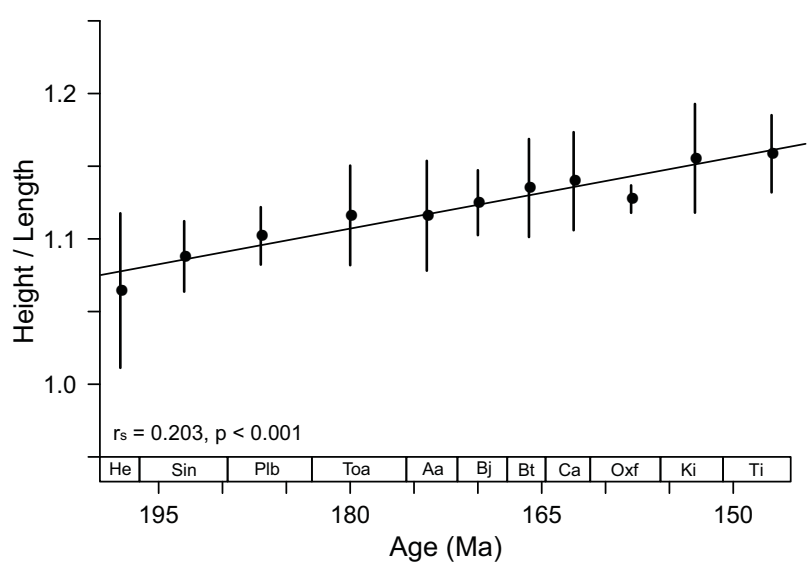

Figure 6. Mean of height-length ratio of Chlamys textoria (Schlotheim, 1820) through time. Error bars represent $95 \%$ confidence intervals. For abbreviations of Jurassic stages see Figure 4. 


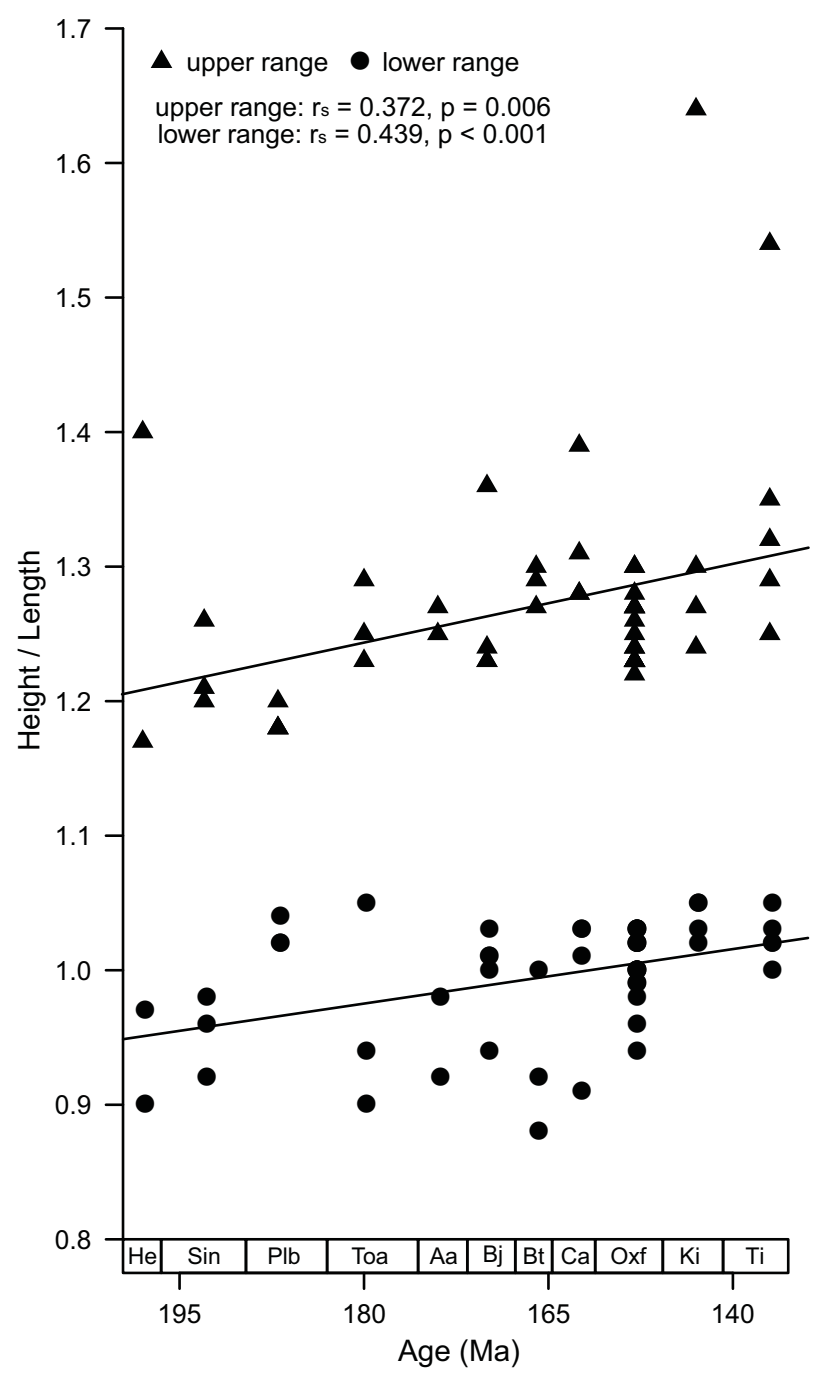

Figure 7. Height-length ratio of Chlamys textoria (Schlotheim, 1820) through time, highlighting trends in specimens with the lowest and the highest values of height to length. The cut-off of each extreme is $10 \%$. For abbreviations of Jurassic stages see Figure 4.

in the lower range, the increase in the average $\mathrm{H} / \mathrm{L}$ through time is obviously the result of the combined effect of increasing both the maximum and the minimum values. Thus, we conclude that the constraints of the minimum test are fulfilled, and the observed trend is a driven one. This suggests that it is not just the result of passive diffusion but implies an underlying driving force.

There is no significant difference in body shape when comparing specimens from the tropics to those from outside the tropics (Mann-Whitney $U, p=0.3$ ). In contrast, the average $\mathrm{H} / \mathrm{L}$ in reef/reef-associated habitats is significantly higher than in non-reef habitats (Mann-Whitney $U, p=0.009$ ). However, the trend in changing body shape through time remains significant when restricting the time series to the Early to Middle Jurassic interval during which the relative abundance of reef-associated specimens was low (Fig. $4 ; r_{\mathrm{s}}=0.270$, $p<0.001)$. Furthermore, the trend is still evident when analysing level bottom habitats $\left(r_{\mathrm{s}}=0.239, p<0.001\right)$, carbonates, siliciclastics, and mixed lithologies $\left(r_{\mathrm{s}}=\right.$ $0.134, p=0.01 ; r_{\mathrm{s}}=0.464, p<0.001 ;$ and $r_{\mathrm{s}}=0.299$, $p=0.01$, respectively), as well as fine-grained and coarse-grained sediments separately $\left(r_{\mathrm{s}}=0.181, p=\right.$ 0.002 , and $r_{\mathrm{s}}=0.211, p=0.01$, respectively).

\section{Latitudinal gradient}

It can be argued that body size, especially of suspension-feeders, is largely dependent on the prevailing productivity regime (Aberhan et al. 2006). We therefore excluded specimens from high productivity areas from the analysis of body-size patterns in the latitudinal cline (see methods).

Although there is no correlation of body size with palaeolatitude when all specimens are considered ( $p>0.1$, but see Table 1 for the "standardised" dataset), analysing specimens from different environments separately shows a weak, but significant, positive correlation of body size with palaeolatitude in shallow-water as well as in deeper water habitats (Fig. 8A). Furthermore, grouping the occurrences into tropical versus non-tropical palaeolatitudes shows a significantly larger mean body size for the specimens from outside the tropics (Mann-Whitney $U, p<0.001$, Fig. 8B).

Assigning specimens to bands of absolute palaeolatitude (using ranges of $5^{\circ}$ latitude) shows no trend in mean body size, but a significant increase in the maximum body size with latitude (Fig. 9).

\section{Ornamentation}

In an attempt to eliminate the effect of an ontogenetic increase in the number of plicae, ornamentation analyses were performed within specific ranges in body size. This approach assumes that growth rates do not differ substantially among specimens, but a detailed quantitative verification, using sclerochronological methods, was beyond the scope of this study. Specimens with a body size (expressed as geometric mean, GM) of 20$40 \mathrm{~mm}$ (GM : 20), 40-60 mm (GM : 40), and > $60 \mathrm{~mm}$ (GM : 60) were grouped and analysed separately.

Phenotype distribution in the complete dataset shows that the "fine" phenotype is the most abundant, with $39.2 \%$ of the specimens belonging to this group, while $34.3 \%$ of the specimens represent the "coarse" phenotype and $26.5 \%$ the "intermediate" phenotype.

Plical frequency in the various environmental categories differs significantly when focusing on specimens in the GM : 20 size range (Kruskal-Wallis $H, p<0.001$ ). Whereas the abundance of the intermediate "phenotype" varies little, specimens from shallow-water habitats exhibit mostly the "coarse" phenotype, and the "fine" phenotype dominates in reefal habitats (Fig. 10). We also find a significant difference in plical density between specimens from coarse-grained and finegrained sediments, with the latter exhibiting on average a higher number of plicae (GM : 20, Mann-Whitney $U$, 

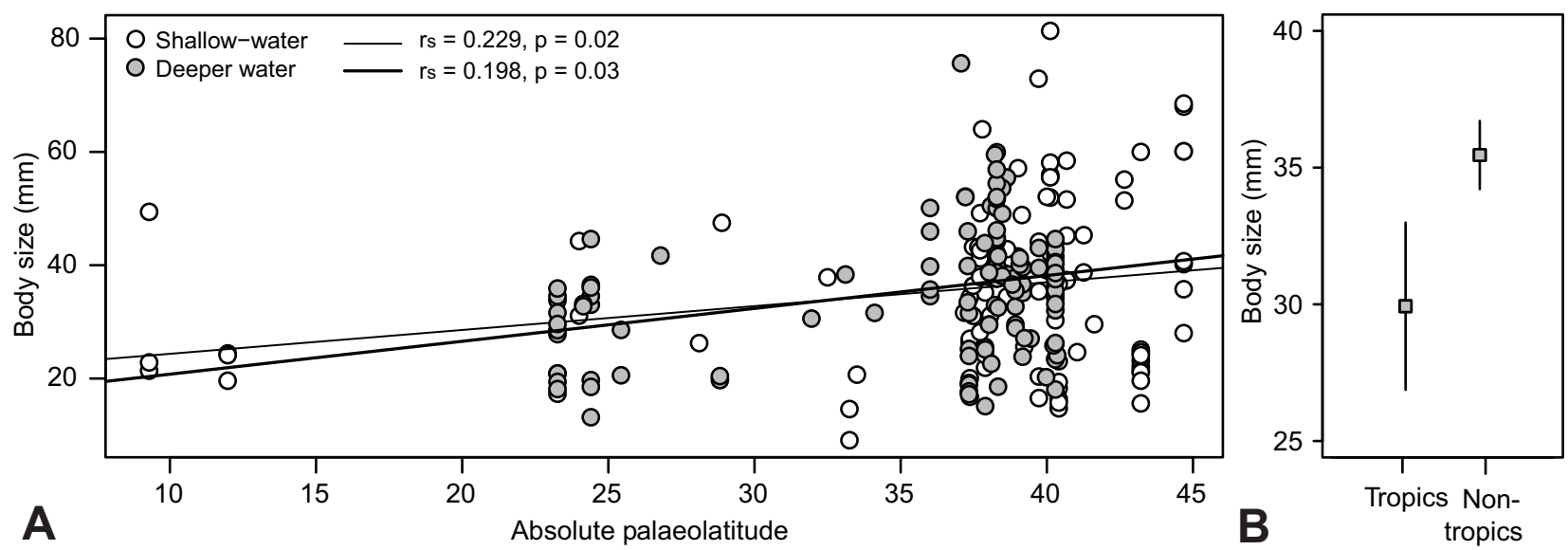

Figure 8. Body size of Chlamys textoria (Schlotheim, 1820) in the palaeolatudinal cline. A. Body size across absolute palaeolatitude for specimens from shallow-water and deeper water habitats; B. Mean body size of Ch. textoria in the tropics versus nontropics. Error bars represent $95 \%$ confidence intervals.

$p<0.001$, Fig. 10). It should be noted that we performed the latter two analyses with strongly overlapping datasets; almost half of the specimens from coarse-grained sediments also contribute to the dataset from shallow-water habitats. Comparing tropical with non-tropical specimens shows no significant difference in phenotype distribution when focusing on Early, Middle, and Late Jurassic specimens separately. These three separate time intervals were used to avoid potential bias by temporal trends in plical frequency (see next paragraph). No significant correlation between plical frequency and environmental category and between plical frequency and grain size has emerged within the two categories of larger specimens (GM : 40 and GM : 60). This is most likely due to the smaller number of specimens within these groupings.

In the GM:20 size class there is a significant positive correlation of plical frequency with time

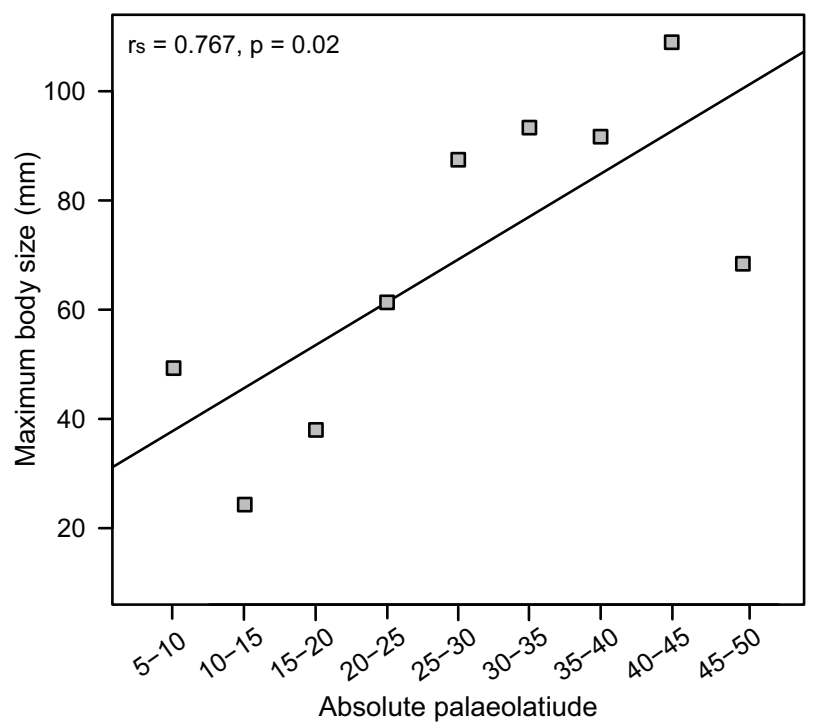

Figure 9. Maximum body size of Chlamys textoria (Schlotheim, 1820) in the palaeolatudinal cline. Quadrangles indicate maximum body size within $5^{\circ}$ palaeolatitudinal intervals. $\left(r_{\mathrm{s}}=0.304, p<0.001\right)$. By contrast, the trends in the groups of GM:40 and GM:60 are negative $\left(r_{\mathrm{s}}=\right.$ $-0.238, p=0.01$ and $r_{\mathrm{s}}=-0.812, p<0.001$, respectively). The strongest positive correlation of plical counts with time (in the group GM : 20) was observed in finegrained sediments $\left(r_{\mathrm{s}}=0.555, p<0.001\right)$, whereas the strongest negative correlation (in the group GM : 40) was observed in coarse-grained sediments $\left(r_{\mathrm{s}}=-0.463\right.$, $p<0.01)$. The positive correlation of plical counts with time is also significant in non-tropical specimens.

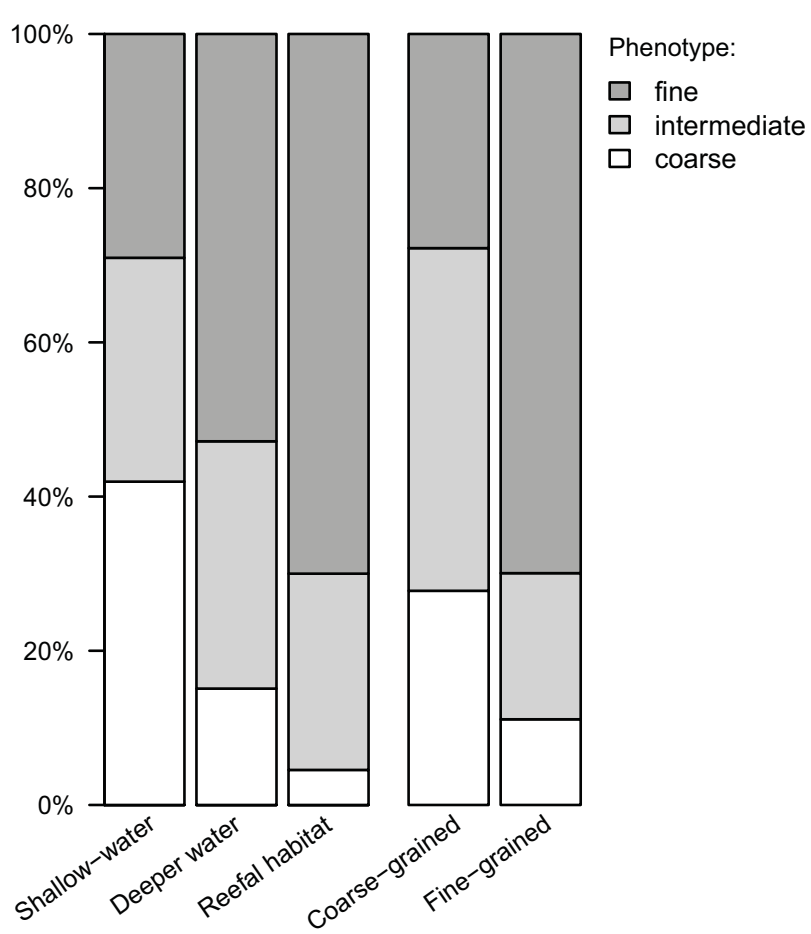

Figure 10. Relative abundance of specimens of Chlamys textoria (Schlotheim, 1820) belonging to the "coarse" (17-26 plicae), "intermediate" (27-36 plicae), and "fine" (>36 plicae) phenotype in the various environmental settings and in coarsegrained versus fine-grained sediments. Only specimens with a geometric mean between 20 and $40 \mathrm{~mm}$ are included. 


\section{Discussion}

\section{Temporal fluctuations in body size}

The trajectory of maximum body size correlates well with the fluctuating values of maximum height provided by Johnson (1984) for specimens from the European Jurassic. In contrast, the lack of a consistent trend in body size deviates from the results of Hallam (1975a), which indicated an evolutionary size increase in Ch. textoria. In that study on an unspecified number of specimens of Ch.textoria, collected over ten stratigraphic biozones from western Europe and representing about $14 \mathrm{Myr}$, an increase in the maximum size from $28 \mathrm{~mm}$ in the earliest Sinemurian to $88 \mathrm{~mm}$ in the latest Pliensbachian was observed, corresponding to a threefold increase in size. These are the records of maximum dimensions attained at the earliest and latest stratigraphic occurrence, but the trajectory of body size in the intermediate time intervals is not known. Hallam's (1975a) species concept differs from ours and his own later work (e.g. Hallam 1987), which resulted in a strongly reduced stratigraphic range of Ch.textoria (Hettangian-Pliensbachian). Although less pronounced than in Hallam's study, our analysis also shows a distinct size increase in the early history of Ch. textoria from the Hettangian to the Pliensbachian (Fig. 5). Our longer time series, however, reveals that there is no long-term trend, and small body size similar to the low in the Hettangian also characterises the Aalenian, Callovian, and Kimmeridgian stages.

Stanley (1973) argued that for every species there will be an optimum body size for the niche it occupies. Whether body size changes at all depends on whether the mean size of the original population is smaller or larger than this adaptive optimum. Hence, a change in body size is most likely to occur in the early stages of a species' evolution and after environmental change. The Hettangian to Pliensbachian size increase in Ch. textoria occurs across more than $16 \mathrm{Myr}$, which seems to be too long to represent the earliest stages of evolution. To address changes in body size early in the evolution of Ch. textoria, a much more continuous sampling within the various biostratigraphic subzones of the Hettangian and Early Sinemurian is necessary, which was beyond the scope of this study. Furthermore, size changes were more pronounced in the Late Jurassic than during the Early Jurassic (Fig. 5), which also argues against the accumulation of changes in body size early on in the lifetime of Ch. textoria.

\section{Evolutionary change in body shape}

The observed gradual increase in the average ratio of height to length through time could theoretically be caused by ontogenetic effects. This would be the case if, during growth, height increases more strongly than length and if younger time intervals had proportionally more large specimens than older time intervals. We can

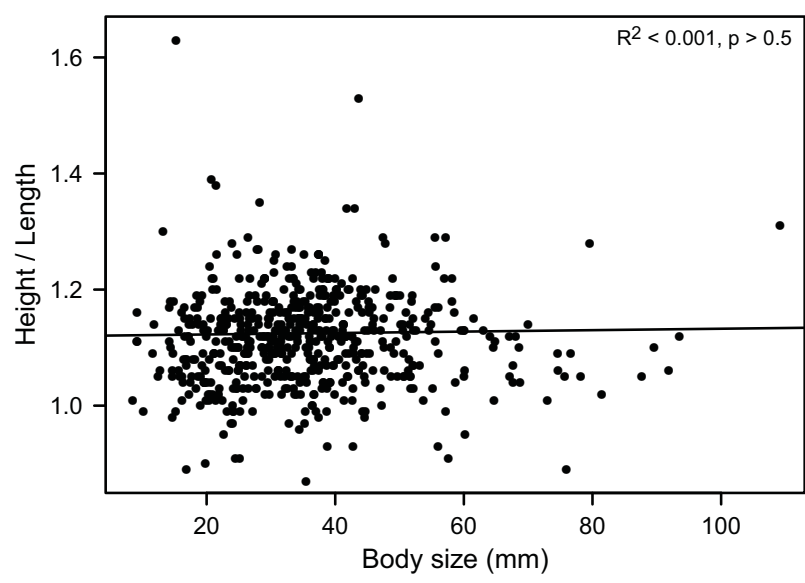

Figure 11. Scatter diagram of the height-length ratio against body size of Chlamys textoria (Schlotheim, 1820).

exclude such an ontogenetic bias for the following reasons: (1) The trend persists within defined size ranges; (2) there is no directional increase in size through time (Fig. 5); and (3) there is no evidence for a disproportionate ontogenetic increase in height relative to length (Fig. 11). This last observation contrasts with Johnson's (1984) contention that Ch. textoria becomes increasingly higher than long towards the maximum height, but his own data do not support this conclusion (see Johnson 1984, fig. 148).

Another potential bias could arise if shell shape differs among regions and the geographic provenance of samples is distributed very unevenly over time. Because the trend is not only evident globally but also within various European regions, we are confident that it is not caused by such a geographic variation in shape.

Finally, the observation that average $\mathrm{H} / \mathrm{L}$ of $\mathrm{Ch}$. textoria is larger in reef and reef-associated habitats than in level bottom habitats, combined with the fact that reefal specimens dominate in the Late Jurassic (Fig. 4), could generate an environmental bias in our dataset. Alternatively, specimens from reef/reef-associated habitats have a higher ratio of height to length because most of them were derived from Upper Jurassic deposits and thus just reflect the general evolutionary trend in body shape. We favour the latter explanation because the temporal trend in changing body shape remains significant when focusing on the Early to Middle Jurassic interval, and because of the persistence of the trend in shallow-water settings and in the various lithological categories. The concentration of reef-derived specimens in the Late Jurassic may have amplified the trend in shape, but this factor alone is not sufficient to account for its existence.

McShea (1994) referred to trends as driven when change is biased in a particular direction because of an adaptive benefit or when anagenetic change occurred. In the latter case, a change in body shape may be explained by genetic drift and does not necessarily signify that any force was acting in the observed direction. We are not aware of an obvious adaptive advantage of an increase in the height to length ratio. The right valve of 
Ch. textoria has a low convexity and an elongate anterior auricle with a deep byssal notch which is retained even in large specimens. Analogous to modern pectinids (Stanley 1970), this probably indicates attachment by a byssus throughout ontogeny with the right valve as the lower valve. Johnson (1984) suggested that Ch. textoria was capable of swimming, consistent with the behaviour of modern pectinids with similar morphology. Whereas low and unequal convexity of the left and right valve is paradigmatic for swimming, we hold that Ch. textoria was at best a poor and infrequent swimmer. Morphologic features supporting this view are the asymmetry of anterior and posterior auricles, a fairly low umbonal angle (cf. Stanley 1970, figs 11, 15), and the existence of radial ribs on the shell exterior. An increase in $\mathrm{H} / \mathrm{L}$ necessarily results in a decrease of the umbonal angle. Because the umbonal angle of the vast majority of specimens of Ch. textoria is already below that of extant pectinids that are able to swim proficiently, an evolutionary increase in $\mathrm{H} / \mathrm{L}$ would diminish the capability to swim even further. The currents expelled from the dorsal commissure during swimming would pass backward less directly, the water volume emitted for propulsion would decrease, and frictional drag in the direction of movement would increase (Stanley 1970). Swimming is an important antipredatory strategy among scallops (Vermeij 1987, but see Aberhan et al. 2012), but despite the apparent increase in predation pressure during the Jurassic (Aberhan et al. 2006) it was not a behaviour which Ch. textoria improved during its Jurassic lifetime.

For lack of an obvious selective advantage that would explain the observed change in shape, we consider genetic drift to be plausible.

\section{Latitudinal gradient}

The range in palaeolatitude of our data from $9^{\circ}$ to $48^{\circ}$ limits our analyses to low and mid palaeolatitudes. Nevertheless, extra-tropical specimens are larger than those from the tropics on average, and - in accordance with Bergmann's rule - we find some support for a significant positive linear trend of body size across latitude. In other studies on marine bivalves, no distinct linear relationship between mean body size and latitude has emerged (Roy et al. 2000; Roy \& Martien 2001). In fact, Roy \& Martien (2001) reported that mean body size for their lowest and highest latitude assemblages in the north-eastern Pacific was surprisingly similar and that it decreased with increasing latitude within the lower province $\left(5^{\circ} \mathrm{S}\right.$ to $\left.23^{\circ} \mathrm{N}\right)$, and increased with increasing latitude in higher provinces $\left(>34.5^{\circ} \mathrm{N}\right)$. Because of the scant occurrences of specimens from low palaeolatitudes in the present study, with only six specimens from palaeolatitudes below $20^{\circ}$, we cannot rule out that similar trends exist among Ch.textoria, and that the reported linear trend is merely caused by the abundant data from mid palaeolatitudes. The small number of specimens from low palaeolatitudes reflects a real paucity of information from tropical regions, a feature typical of much of the Late Mesozoic fossil record (Koch 1998) that hampers latitudinal analyses in general. Nevertheless, the increase in maximum body size from low to mid palaeolatitudes supports the idea of a linear trend, even though analysis on maximum body sizes does not necessarily reflect the shift in size distribution within the whole population. Furthermore, the existence of a latitudinal size trend in Ch. textoria in shallow-water and deeper water environments suggests that the trend is not facies-controlled.

Our analyses confirm that there are other factors that affect body size besides the positive correlation of energy availability with temperature and growth rate (see Turner \& Lennon 1989). Temperature-independent environmental factors such as salinity, substrate, and water depth also influence growth of marine animals (Heilmayer 2004). Based on the effect of temperature on a number of invertebrates, including two bivalve species, Atkinson (1994) even argued that body size at a given developmental stage decreases despite increasing temperature. Atkinson proposed several explanations for the phenomenon, including temperature-dependent changes in the oxygen-carrying capacity of water and the benefit of maturation at smaller size in populations with higher density (see also Blackburn et al. 1993). Similarly, though it has been shown that bivalves from low latitudes tend to grow more rapidly than conspecifics from higher latitudes (Gosling 2003) at least some also attain a smaller maximum size and have a shorter lifespan (Newell 1964). Thus, understanding the ultimate causes of latitudinal trends in body size in an extinct bivalve species can be quite complex because multiple factors can covary with temperature trends.

\section{Ornamentation}

Our results confirm quantitatively the observation of Johnson (1984) that plical counts vary for specimens from different environments. In a study on Jurassic trigoniid bivalves, Francis \& Hallam (2003) considered it unlikely that change in costal density had any adaptive significance, and differences in costal density may simply be the result of genetic shift in the population. Because the variation in Ch. textoria is clearly linked to the inhabited environment, we propose that, for this species, changes in plical counts have an adaptive significance.

Johnson (1984) proposed that the variation in plical frequency is an ecophenotypic phenomenon, but this cannot explain his observation that there is no perfect correspondence of phenotype with facies. In our view, an ecophenotypic explanation is not compulsory, and the pattern can rather be interpreted as a phenomenon caused by natural selection. For example, if higher plical amplitudes are in fact an effective defence against predators (because of increased shell strength; see 
Alexander 1990; Zuschin et al. 2003), increasing predation pressure would lead to an increased survivorship of individuals with fewer but larger plicae compared to individuals with more numerous but less prominent plicae. Eventually, this would lead to differing genotype (and phenotype) frequencies for the populations in the various habitat types. Larger plical amplitudes do not provide a perfect protection against predators, and obviously some of the specimens exhibiting the "intermediate" or "fine" phenotype did reach maturity in each habitat type. Only the percentage of the phenotypes in the population changes with increasing predation pressure.

Johnson (1984) speculated that some environmental variable, which is only loosely related to sedimentary facies, is the real determinant of phenotype dominance. In this context, he considered different defence strategies (e.g. escape from predators via swimming; increased resistance against attack by predators), depending on the environment. Alternatively, he suggested that camouflage, relating to the grain size of the substrate, might be an explanation.

We consider Johnson's defence-based hypothesis to be an unlikely explanation for the observed phenotype distribution in Ch. textoria, because it assumes different strategies towards predators in different environments. An alternative to the defence-based hypothesis would be a gradient in predation risk. Such gradients have been documented in the fossil record (Hoffmeister \& Kowalewski 2001; Sawyer \& Zuschin 2010) as well as in modern environments (Fawcett 1984; Canion \& Heck 2009). In marine environments, predation pressure is typically highest in the lower intertidal and shallow subtidal zones and then decreases shoreward and seaward (Fawcett 1984; Sawyer \& Zuschin 2010). The predation pressure characteristic of reefs is difficult to determine due to the complexity of the ecosystem. Reefs are characterised by a high number of predators, but they also contain numerous predation refuges in the form of crevices and cryptic micro-habitats. Such refugia have been shown to reduce predation risk in some environments (Menge \& Lubchenco 1981). It is therefore possible that predation risk may be rather low in reef environments. Under this scenario, the observed pattern in phenotype distribution can be seen as a response to the gradient in predation risk: the higher the predation pressure, the lower the average plical count.

The camouflage hypothesis may provide the best explanation for the phenotype distribution because it does not depend on an assumed gradient in predation risk. Several extant pectinids (e.g. Pecten ziczac, Pecten maximus) are known to excavate a depression on the substrate in which they sit, and to cover and thus camouflage their upper flat valve with silt, sand or gravel (e.g. Stanley 1970; Franklin et al. 1980). The combination of plicae and lamellae produces a grating that could function as an imitation of the predominant substrate in the absence of vegetation. Moreover, finegrained sediment may serve to efficiently hide the shell by filling of the narrow interspaces between ribs of the "fine" phenotype, whereas coarse grains are better suited to fill the broader interspaces of the "coarse" phenotype. The better the camouflage, the lower the probability of encountering a predator and the greater are the chances of survivorship and increase in the number of individuals with the advantageous phenotype. Because grain size and habitat often correlate - most of the deeper water habitats have fine-grained sediments and shallow-water habitats have coarser sediments - the camouflage hypothesis also explains the lower abundance of the "coarse" phenotype in deeper water habitats. Thus, this hypothesis satisfactorily accounts for the phenotype distribution in Ch. textoria and can explain the lack of a perfect phenotype correspondence. It is also a good explanation for the lack of a significant difference in phenotype distribution between the tropics and extra-tropics; if grain size is the controlling factor, and the relative abundance of fine- and coarse-grained sediments is about the same in both latitudinal categories, we expect no major difference, even if predation is more intense in the tropics (Dietl \& Kelley 2001; Freestone et al. 2011).

Although seemingly contradictory, the observed temporal trends can be reconciled with the camouflage hypothesis. Higher plical counts should be favoured in habitats with fine-grained sediments, and lower plical counts should be favoured in habitats with coarser sediments. Accordingly, the percentage of the favoured phenotype should increase with time in each habitat type: plical frequency should increase and decrease with time in fine- and coarse-grained habitats, respectively. This is in agreement with our results, which show the strongest positive correlation of plical frequency with time in fine-grained sediments (in size class GM : 20), and the strongest negative correlation in coarse-grained sediments (in size class GM : 40). Obviously, the actual benefit of fine-tuning grain size and number of plicae is not essential for survival. In combination with a continuous increase in predation pressure during the Jurassic, this could explain that the above shifts in phenotype composition extend across evolutionary (tens of millions of years) rather than ecological time scales.

\section{Conclusions}

Detailed analysis suggests that the established patterns and trends reflect true biological/evolutionary signals and are not artifacts of an uneven representation of environmental and lithological categories in the data set. We show that: (1) body size of Ch. textoria fluctuated during the Jurassic without any long-term trend; (2) the average ratio of height to length increased gradually during the Jurassic; (3) mean body size increased from low to mid palaeolatitudes; and (4) a strong but complex relationship exists between the number and strength of the radial ribs of Ch. textoria and the inhabited environments. 
With respect to "rules", we conclude that Cope's rule does not apply for this species. We find some evidence supporting the applicability of Bergmann's rule but the establishment of a definitive link between size and latitude in this species is not possible at this time because of the low number of specimens from low palaeolatitudes and the current restriction of the range of Ch. textoria to palaeolatitudes lower than $48^{\circ}$.

In terms of processes, our analyses confirm that the positive relationship between temperature and growth rate does not alone determine body size. The directional change in shape suggests that swimming abilities, if anything, decreased over time. The phenotype distribution suggests that Ch. textoria rather applied an adaptive camouflage strategy to avoid predation. Genetic drift is a more plausible mechanism to generate the trend in shape than operation of a specific selective force.

\section{Acknowledgements}

We would like to thank Franz Fürsich and Peter Harries for critical reviews of the manuscript.

\section{References}

Aberhan, M. 1994. Early Jurassic Bivalvia of northern Chile. Part I. Subclasses Palaeotaxodonta, Pteriomorphia, and Isofilibranchia. Beringeria 13: 1-115.

Aberhan, M. 1998a. Early Jurassic Bivalvia of western Canada. Part I. Subclasses Palaeotaxodonta, Pteriomorphia, and Isofilibranchia. Beringeria 21: 57-150.

Aberhan, M. 1998b. Paleobiogeographic patterns of pectinoid bivalves and the Early Jurassic tectonic evolution of western Canadian terranes. - Palaios 13: 129-148.

Aberhan, M., Kiessling, W. \& Fürsich, F. T. 2006. Testing the role of biological interactions for the evolution in mid-Mesozoic marine benthic ecosystems. - Paleobiology 32: 259-277.

Aberhan, M., Nürnberg, S. \& Kiessling, W. 2012. Vision and the diversification of Phanerozoic marine invertebrates. - Paleobiology 38 (2).

Agrawal, S. K. 1956. Contribution à l'étude stratigraphique et paléontologique du Jurassique du Kutch (Inde). - Annales du Centre d'Études et de Documentation Paléontologiques 19: 1-188.

Ahmad, F. 1999. Middle Jurassic macroinvertebrates from northwestern Jordan. - Beringeria 23: 3-46.

Allasinaz, A. 1962. Il Trias in Lombardia (Studi geologici e palaeontologici). III. Studio palaeontologico e biostratigrafico del Retico die dintorni di Endine (Bergamo). - Rivista Italiana di Paleontologia e Stratigrafia 68: 307-376.

Alexander, R. R. 1990. Mechanical strength of shells of selected extant articulate brachiopods: Implications for Paleozoic morphologic trends. - Historical Biology 3: 169-188

Alroy, J. 1998. Cope's rule and the dynamics of body mass evolution in North American fossil mammals. - Science 280: 731-734.

Atkinson, D. 1994. Temperature and organism size - a biological law for ectotherms? - Advances in Ecological Research 25: 1-58.

Arnold, A. J., Kelly, D. C. \& Parker, W. C. 1995. Causality and Cope's rule: Evidence from the planktonic foraminifera. - Journal of Paleontology 69: 203-210.

Bambach, R. K. 2002. Supporting predators: Changes in the global ecosystem inferred from changes in predator diversity. In Kowa- lewski, M. \& Kelley, P. H. (eds). The Fossil Record of Predation. - The Paleontological Society Papers 8: 319-351.

Berini, L. 1957. Studi palaeontologici sul Lias del Monte Albenza (Bergamo). Lamellibranchi e gastropodi del Lias inferiore. - Rivista Italiana di Paleontologia e Stratigrafia 63: 31-60.

Bertuletti, C. 1962. Studi palaeontologici sul Lias del Monte Albenza (Bergamo). I Lamellibranchi dell'Hettangiano (1). - Rivista Italiana di Paleontologia e Stratigrafia 68: 169-192.

Blackburn, T. M., Brown, V. K., Doube, B. M., Greenwood, J. J. D., Lawton, J. H. \& Stork, N. E. 1993. The relationship between abundance and body size in natural animal assemblages. - Journal of Animal Ecology 62: 519-528.

Butler, R. J. \& Goswami, A. 2008. Body size evolution in Mesozoic birds: Little evidence for Cope's rule. - Journal of Evolutionary Biology 21: 1673-1682.

Calzada, S. \& Radulovic, V. 1987. About two bivalvian species from Klaus-Schichten. - Revue de Paléobiologie 6: 19-22.

Canion, C. R. \& Heck, K. L., Jr. 2009. Effect of habitat complexity on predation success: Re-evaluating the current paradigm in seagrass beds. - Marine Ecology Progress Series 393: 37-46.

Cantaluppi, G. \& Corti, S. 1969. La fauna della "pietra di Moltrasio" (Como). - Natura. Rivista di Scienze Naturali 60: 103-133.

Chown, S. L. \& Gaston, K. J. 2010. Body size variation in insects: A macroecological perspective. - Biological Reviews 85: 139-169.

Contejean, C. 1859. Étude de l'etage Kimméridien dans les environs des Montbéliard et dans le Jura. - Mémoires de la Société d'Emulation du Doubs: 1-352.

Cope, E. D. 1896. The Primary Factors of Organic Evolution. Open Court Publishing Company, Chicago.

Cossmann, M. 1911. Description de quelques pélécypodes jurassiques receuillis en France. - Comptes Rendus de l'Association Française pour l'Avancement des Sciences (Congrès de Dijon), $1^{\text {ere }}$ sér., $4^{\mathrm{e}}$ art.: $1-10$.

Cottreau, J. 1925-1932. Types du Prodrome de Paléontologie stratigraphique universelle d'Alcide d'Orbigny. Tome II. CallovienPortlandien. - Annales de Paléontologie 14: 133-164, 17: 49-80, 18: $141-176$.

Cox, L. R. 1965. Jurassic Bivalvia and Gastropoda from Tanganyika and Kenya. - Bulletin of the British Museum (Natural History), Geology, Supplement 1: 1-213.

Damborenea, S. E. 2002. Early Jurassic bivalves of Argentina: Part 3, Superfamilies Monotoidea, Pectinoidea, Plicatuloidea and Dimyoidea. - Palaeontographica A 265: 1-119.

Dayan, T., Simberloff, D., Tchernov, E. \& Yomtov, Y. 1991. Calibrating the paleothermometer: climate, communities, and the evolution of size. - Paleobiology 17: 189-199.

Dechaseaux, C. 1936. Pectinidés jurassiques de l'est du Bassin de Paris. - Annales de Paléontologie 25: 1-148.

Defrance, M. J. L. 1825. Mémoire géologique sur les terrains de la Normandie de M. de Caumont. - Mémoires de la Linnéene Société de Normandie 2: 1-507.

Delvene, G. 2001. Middle and Upper Jurassic bivalves from the Iberian Range (Spain). - Beringeria 28: 43-104.

Dietl, G. P. \& Kelley, P. H. 2001. Mid-Paleozoic latitudinal predation gradient: Distribution of brachiopod ornamentation reflects shifting Carboniferous climate. - Geology 29: 111-114.

Dommergues, J. L., Montuire, S. \& Neige, P. 2002. Size patterns through time: The case of the early Jurassic ammonite radiation. Paleobiology 28: 423-434.

Ernst, W. 1923. Beiträge zur Paläontologie und Stratigraphie des nordwestdeutschen Jura. IV. Zur Stratigraphie und Fauna des Lias $\zeta$ im nordwestlichen Deutschland (erster Teil). - Palaeontographica 65: 1-96.

Fawcett, M. H. 1984. Local and latitudinal variation in predation on an herbivorous marine snail. - Ecology 65: 1214-1230.

Fischer, J.-C. 1964. Contribution à l'étude de la faune bathonienne dans la vallée de la Creuse (Indre): Brachiopods et Mollusques. Annales de Paléontologie (Invertébrés) 50: 19-101. 
Francis, A. O. \& Hallam, A. 2003. Ecology and evolution of Jurassic trigoniid bivalves in Europe. - Lethaia 36: 287-304.

Franklin, A., Pickett, G. D. \& Connor, P. M. 1980. The scallop and its fishery in England and Wales. - Ministry of Agriculture, Fisheries and Food, Laboratory Leaflet 51: 1-19.

Freestone, A. L., Osman, R. W., Ruiz, G. M. \& Torchin, M. E. 2011. Stronger predation in the tropics shapes species richness patterns in marine communities. - Ecology 92: 983-993.

Fürsich, F. T. \& Werner, W. 1988. The Upper Jurassic Bivalvia of Portugal. Part II. Pteriomorphia (Pterioida exclusive Ostreina). Comunicações dos Serviços Geológicos de Portugal 74: 105-164.

Gaetani, M. 1970. Faune Hettangiane della parte orientale della provincia di Bergamo. - Rivista Italiana di Paleontologia e Stratigrafia 76: $355-442$.

Gemmellaro, G. G. \& di Blasi, A. 1874. Pettini del Titonio inferiore del nord di Sicilia. - Atti della Accademia Gioenia di Scienze Naturali in Catania 9: 95-138.

Golonka, J., Ross, M. I. \& Scotese, C. R. 1994. Phanerozoic paleogeographic and paleoclimatic modeling maps. In Embry, A. F., Beauchamp, B. \& Glass, D. J. (eds). Pangea. - Canadian Society of Petroleum Geologists, Memoir 17: 1-47.

Gosling, E. 2003. Bivalve Molluscs - Biology, Ecology and Culture. Fishing News Books, Blackwell Publishing, Oxford

Gradstein, F. M. \& Ogg, J. G. 2004. Geologic time scale 2004 - why, how, and where next! - Lethaia 37: 175-181.

Greco, B. 1898. Fauna della Zona con Lioceras opalinum Rein. sp. di Rossano in Calabria. - Palaeontographica Italica 4: 93-139.

Greppin, E. 1893. Études sur les mollusques des couches coralligènes des environs d'Oberbuchsiten. - Mémoires de la Société Paléontogique Suisse 20: 1-109.

Greppin, E. 1898-1900. Description des fossiles du Bajocien supérieur des environs de Bâle. - Mémoires de la Société Paléontogique Suisse 25: 1-52, 26: 53-126, 27: 127-210.

Hallam, A. 1975a. Evolutionary size increase and longevity in Jurassic bivalves and ammonites. - Nature 258: 493-496.

Hallam, A. 1975b. Jurassic Environments. Cambridge University Press, Cambridge.

Hallam, A. 1978. How rare is phyletic gradualism and what is its evolutionary significance? Evidence from Jurassic bivalves. - Paleobiology 4: 16-25.

Hallam, A. 1987. Radiations and extinctions in relation to environmental change in the marine Lower Jurassic of northwest Europe. - Paleobiology 13: 152-168.

Hallam, A. 1998. Speciation patterns and trends in the fossil record. Geobios 30: 921-930.

Hayami, I. 1957. Liassic Chlamys, "Camptonectes" and other pectinids from the Kuruma Group in Central Japan. - Transactions and Proceedings of the Palaeontological Society of Japan. New Series 28: 119-127.

Heilmayer, O. 2004. Environment, adaptation and evolution: Scallop ecology across the latitudinal gradient. - Berichte zur Polar- und Meeresforschung 480: 1-161.

Hoffmeister, A. P. \& Kowalewski, M. 2001. Spatial and environmental variation in the fossil record of drilling predation: A case study from the Miocene of central Europe. - Palaios 16: 566-579.

Hone, D. W. E. \& Benton, M. J. 2005. The evolution of large size: How does Cope's rule work? - Trends in Ecology and Evolution 20: 4-6.

Hone, D. W. E. \& Benton, M. J. 2007. Cope's rule in the Pterosauria, and differing perceptions of Cope's rule at different taxonomic levels. - Journal of Evolutionary Biology 20: 1164-1170.

Hone, D. W. E., Dyke, G. J., Haden, M. \& Benton, M. J. 2008. Body size evolution in Mesozoic birds. - Journal of Evolutionary Biology 21: 618-624.

Hunt, G. \& Roy, K. 2006. Climate change, body size evolution, and Cope's rule in deep-sea ostracodes. - Proceedings of the National Academy of Sciences (USA) 103: 1347-1352.
Hunt, G., Wicaksono, S. A., Brown, J. E. \& MacLeod, K. G. 2010. Climate-driven body-size trends in the ostracod fauna of the deep Indian Ocean. - Palaeontology 53: 1255-1268.

Hurst, U. 1992. Die Bivalvenfauna der Schwammkalke von Biburg (Oberoxford, Südliche Frankenalb). Pteriomorpha III. - Mitteilungen der Bayerischen Staatssammlung für Paläontologie und historische Geologie 32: 69-86.

Jablonski, D. 1996. Body size and macroevolution. In Jablonski, D., Erwin, D. H. \& Lipps, J. H. (eds). Evolutionary Paleobiology. University of Chicago Press, Chicago: pp. 256-289.

Jablonski, D. 1997. Body-size evolution in Cretaceous molluscs and the status of Cope's rule. - Nature 385: 250-252.

Jaitly, A. K., Fürsich, F. T. \& Heinze, M. 1995. Contributions to the Jurassic of Kachchh, western India. IV. The bivalve fauna. Part I. Subclasses Palaeotaxodonta, Pteriomorphia, and Isofilibranchia. Beringeria 16: 147-257

Johnson, A. L. A. 1984. The palaeobiology of the bivalve families Pectinidae and Propeamussidae in the Jurassic of Europe. - Zitteliana 11: 1-235

Knouft, J. H. \& Page, L. M. 2003. The evolution of body size in extant groups of North American freshwater fishes: Speciation, size distributions, and Cope's rule. - American Naturalist 161: 413421

Koch, C. F. 1998. 'Taxonomic barriers' and other distortions within the fossil record. In Donovan, S. K. \& Paul, C. R. C. (eds). The Adequacy of the Fossil Record. Wiley, Chichester, England: pp. 189-206.

Kochanová, M. 1979. Die Bivalven des Jura der Vrsatec-Klippe. Západné Karpaty, Seria Palaeontólogia 4: 7-34.

Kosnik, M. A., Jablonski, D., Lockwood, R. \& Novack-Gottshall, P. M. 2006. Quantifying molluscan body size in evolutionary and ecological analyses: Maximizing the return on data-collection efforts. Palaios 21: 588-597.

Kowalewski, M., Simões, M. G., Torello, F. F., Mello, L. H. C. \& Ghilardi, R. P. 2000. Drill holes in shells of Permian benthic invertebrates. - Journal of Paleontology 74: 532-543.

Krause, R. A., Stempien, J. A., Kowalewski, M. \& Miller, A. I. 2007. Body size estimates from the literature: Utility and potential for macroevolutionary studies. - Palaios 22: 60-73.

Kuhn, O. 1936. Die Fauna des Amaltheentons (Lias $\delta$ ) in Franken. Neues Jahrbuch für Mineralogie, Geologie und Paläontologie, Beilagenband (B) 75: 231-311.

Kuhn, O. 1938. Die Fauna des Dogger $\delta$ der Frankenalb (Mit Nachträgen zum übrigen Jura). - Nova Acta Leopoldiana, Neue Folge 6 (37): 125-170.

Lentini, F. 1973. I molluschi del Lias inferiore di Longi (Sicilia nordorientale). - Bolletino della Società Palaeontologica Italiana 12: 23-75.

Loriol, P. de 1904. Ètude sur les mollusques et brachiopodes de l'Oxfordien supérieur et moyen du Jura Lédonien. - Mémoires de la Société Paléontogique Suisse 31: 161-303.

McFadden, B. J. 1992. Fossil Horses: Systematics, Paleobiology, and Evolution of the Family Equidae. Cambridge University Press, Cambridge, U.K.

McShea, D. W. 1994. Mechanisms of large-scale evolutionary trends. Evolution 48: 1747-1763.

Melville, R. V. 1956. Stratigraphical palaeontology; ammonites excluded, of the Stowell Park Borehole. - Bulletin of the Geological Survey of Great Britain 11: 67-139.

Menge, B. A. \& Lubchenco, J. 1981. Community organization in temperate and tropical rocky inter-tidal habitats: Prey refuges in relation to consumer pressure gradients. - Ecological Monographs 51: 429-450.

Moen, D. S. 2006. Cope's rule in cryptodiran turtles: Do the body sizes of extant species reflect a trend of phyletic size increase? Journal of Evolutionary Biology 19: 1210-1221. 
Monroe, M. J. \& Bokma, F. 2010. Little evidence for Cope's rule from Bayesian phylogenetic analysis of extant mammals. - Journal of Evolutionary Biology 23: 2017-2021.

Newell, N. D. 1949. Phyletic size increase, an important trend illustrated by fossil invertebrates. - Evolution 3: 103-124.

Newell, N. D. 1964. Physiological variation in intertidal molluscs. In Wilbur, K. M. \& Yonge, C. M. (eds). Physiology of Molluscs, Volume 1. Academic Press, New York: pp. 59-87.

Nicol, D. 1964. An essay on the size of marine pelecypods. - Journal of Paleontology 38: 968-974.

Novack-Gottshall, P. M. \& Lanier, M. A. 2008. Scale-dependence of Cope's rule in body size evolution of Paleozoic brachiopods. Proceedings of the National Academy of Sciences (USA) 105: 5430-5434.

Orbigny, A. d' 1850. Prodrome de paléontologie stratigraphique universelle des animaux mollusques et rayonnés, Volumes 1-2. Masson, Paris

Paine, R. T. 1976. Size-limited predation: an observational and experimental approach with the Mytilus-Pisaster interaction. - Ecology 57: 858-873.

Paris, E. T. \& Richardson, L. 1915. Some Inferior Oolite Pectinidae. Quarterly Journal of the Geological Society of London 71: 521535 .

Poulin, R. 2005. Evolutionary trends in body size of parasitic flatworms. - Biological Journal of the Linnean Society 85: 181-189.

R Development Core Team 2011. R: A language and Environment for Statistical Computing. R Foundation for Statistical Computing. Vienna, Austria (http://www.R-project.org).

Renaud, S., Benammi, M. \& Jaeger, J. J. 1999. Morphological evolution of the murine rodent Paraethomys in response to climatic variations (Mio-Pleistocene of North Africa). - Paleobiology 25: 369-382.

Roy, K., Jablonski, D. \& Martien, K. K. 2000. Invariant size-frequency distributions along a latitudinal gradient in marine bivalves. Proceedings of the National Academy of Sciences (USA) 97: $13150-13155$

Roy, K. \& Martien, K. K. 2001. Latitudinal distribution of body size in north-eastern Pacific marine bivalves. - Journal of Biogeography 28: 485-493.

Sawyer, J. A. \& Zuschin, M. 2010. Intensities of drilling predation of molluscan assemblages along a transect through the northern Gulf of Trieste (Adriatic Sea). - Palaeogeography Palaeoclimatology Palaeoecology 285: 152-173.

Schlotheim, E. F. von 1820. Die Petrefactenkunde. Becker, Gotha.

Scholz, H. 2005. Taxonomie der Muschelfauna aus dem Oberjura von Hildesheim (N-Deutschland). - Beringeria 35: 3-52.

Sibiriakova, L. V. 1961. Eine mitteljurassische Molluskenfauna der Großen Balchan und ihre stratigraphische Deutung (Sredneyurskaya fauna mollyuskov Bolshogo Balkhana i ee stratigraficheskoe znachenie). - Trudy VSEGEI, n.s. 47: 1-233.

Sime, L. C. \& Ferguson, R. I. 2003. Information on grain sizes in gravel-bed rivers by automated image analysis. - Journal of Sedimentary Research 73: 630-636.
Skwarko, S. K. 1974. Jurassic Fossils of Western Australia. Bajocian Bivalvia of the Newmarracarra Limestone and the Kojarena Sandstone. - Bulletin of the Bureau of Mineral Reserves, Geology and Geophysics 150: 57-109.

Staesche, K. von 1926. Die Pectiniden des Schwäbischen Jura. Geologische und Paläontologische Abhandlungen 15: 1-136.

Stanley, S. M. 1970. Relation of shell form to life habits in the Bivalvia. - Memoirs of the Geological Society of America 125: 1296.

Stanley, S. M. 1973. An explanation for Cope's Rule. - Evolution 27 $1-26$.

Thurmann, J. \& Etallon, A. 1862. Lethea Bruntrutana ou études paléontologiques et stratigraphiques sur le Jura Bernois et en particular les environs de Porrentruy. - Denkschriften der schweizerischen naturforschenden Gesellschaft 19: 147-354.

Tilmann, N. 1917. Die Fauna des unteren und mittleren Lias in Nordund Mittel-Peru. - Neues Jahrbuch für Mineralogie, Geologie und Paläontologie, Beilagenband (B) 41: 628-712.

Turner, J. R. G. \& Lennon, J. J. 1989. Species richness and the energy theory. - Nature 340: 351.

Tzankov, V. \& Boncev, E. 1932. La faune liasique de Kalotina - Bulgarie du l'ouest. - Review of the Bulgarian Geological Society 4: $221-242$.

Vermeij, G. J. 1987. Evolution and Escalation. Princeton University Press, Princeton, NJ.

Vu Khuc, Vu Chau, Trinh Dzanh, Dang Tran Huyen, Nguyen Dinh Huu \& Trinh Tho 1991. Palaeontological Atlas of Vietnam. Volume 3. Mollusca. Geological Survey of Vietnam, Institute of Geology and Mineral Resources, Science and Technics Publishing House, Hanoi.

Wandel, G. 1936. Beiträge zur Kenntnis der jurassischen Molluskenfauna von Misol, Ost-Celebes, Buton, Serran und Jamdena. Neues Jahrbuch für Mineralogie, Geologie und Paläontologie, Beilagenband (B) 75: 447-526.

Weaver, C. E. 1931. Palaeontology of the Jurassic and Cretaceous of West Central Argentina. - Memoirs of the University of Washington 1: 1-469.

Wisniewska-Zelichowska, M. 1971. Fauna of the Jurassic bioherms at Rudniki, near Czestochowa (Central Poland). - Instytut Geologiczny, Biuletyn 243: 5-77.

Yamani, S.-A. 1975. Bivalven-Fauna der Korallenkalke von Laisacker bei Neuburg a. d. Donau, unteres Tithonium, Bayern. - Palaeontographica A 149: 31-118.

Yin, J. \& Fürsich, F. T. 1991. Middle and Upper Jurassic bivalves from the Tanggula Mountains, W-China. - Beringeria 4: 127192.

Yin, T.-H. 1931. Étude de la faune tithonique coralligène du Gard et de 1'Hérault. - Travaux du Laboratoire de Géologie de l'Université de Lyon, Mémoire 17: 1-200.

Zuschin, M., Stachowitsch, M. \& Stanton, R. J. 2003. Patterns and processes of shell fragmentation in modern and ancient marine environments. - Earth Science Reviews 63: 33-82. 